Editorial

\title{
A Marriage of Convenience: Responsive Populists and Responsible Experts
}

\author{
Petra Guasti ${ }^{1, *}$ and Lenka Buštíková ${ }^{2}$ \\ ${ }^{1}$ Institute of Sociology of the Czech Academy of Sciences, 11000 Prague, Czech Republic; \\ E-Mail: guasti@soz.uni-frankfurt.de \\ 2 School of Politics and Global Studies, Arizona State University, Tempe, AZ 85287, USA; E-Mail: lenka.bustikova@asu.edu \\ * Corresponding author
}

Submitted: 30 November 2020 | Published: 17 December 2020

\begin{abstract}
This thematic issue, "Varieties of Technocratic Populism around the World," investigates ideological origins of technocratic populism and situates it among other types of populism. It is composed of 11 articles that bring together 18 scholars from around the world with a wide variety of perspectives. Technocratic populism is an output-oriented populism that directly links voters to leaders via expertise. It emerges as a response to a crisis of governance, reproaches mainstream parties for it and offers solutions that challenge traditional left-right divisions in politics. New leaders combine populism with technocracy: They offer expertise, often harnessed in business, but also a direct, personalized link to 'ordinary' citizens. Above all, they politicize expertise to gain legitimacy. Technocratic populism primarily responds to frustrations of the electorate with poor governance, not to nativist grievances or to the plight of the most vulnerable citizens. In a new social contract, it is expected that voters renounce politics and political parties and that they turn into spectators who observe how technocratic elites adopt solutions that benefit the 'ordinary people.' Technocratic populism is a growing challenge to pluralistic forms of representative democracy and calls for further scholarly attention.
\end{abstract}

\section{Keywords}

expertise; governance; grievance; pandemic; populism; technocracy; technocratic populism

\section{Issue}

This editorial is part of the issue "Varieties of Technocratic Populism around the World" edited by Petra Guasti (Institute of Sociology of the Czech Academy of Sciences, Czech Republic) and Lenka Buštíková (Institute of Sociology of the Czech Academy of Sciences, Czech Republic / Arizona State University, USA).

(C) 2020 by the authors; licensee Cogitatio (Lisbon, Portugal). This article is licensed under a Creative Commons Attribution 4.0 International License (CC BY).

\section{Introduction}

This thematic issue, "Varieties of Technocratic Populism around the World," investigates ideological origins of technocratic populism and situates it among other types of populism. Technocratic populism is an outputoriented populism that directly links voters to leaders via expertise. It emerges as a response to a crisis of governance, reproaches mainstream parties for it and offers solutions that challenge traditional left-right divisions in politics. New leaders combine populism with technocracy: They offer expertise, often harnessed in business, but also a direct, personalized link to 'ordinary' citizens. Above all, they politicize expertise to gain legitimacy.
Technocratic populism is rooted in two alternatives to representative democracy-technocracy and populism (Bickerton \& Accetti, 2017, 2021; Caramani, 2017). Citizens face the duality of technocratic populism. Populism is responsive and places the 'people' at the epicenter of democracy (Kaltwasser, 2014). Technocracy stands for responsible governance, expertise, competence, effectiveness, and 'optimal outcomes.' It is distinct from bureaucracy, which is a mode of governance, because technocracy is a logic of governance. Technocratic approaches focus on problem-solving and conflict neutralization (O'Donnell, 1994), and emphasize a regulatory state that makes rules and monitors their implementation (Majone, 1994). 
Populists and technocrats are anti-political actors with an 'unmediated,' proceduralist view of democracy (Rosanvallon, 2011; Taggart, 2002), which implies that they embrace a non-pluralist concept of a society, the existence of a unified general interest, and a direct, unmediated, relationship between the people and their leaders. Technocratic populism is an anti-elite ideology that instrumentalizes governance and exploits competence. Technocratic populists cultivate the appearance of authenticity and proximity to the ordinary people but also demobilize the electorate by instilling civic apathy (Buštíková \& Guasti, 2019). In many instances, technocratic populists claim to 'run the state as a firm,' which gives them cover to delegitimize political opponents because they lack 'expertise' and relish in the cycles of parliamentary deliberations.

Technocratic populism primarily responds to frustrations of the electorate with poor governance, not to nativist grievances or to the plight of the most vulnerable citizens. In a new social contract, it is expected that voters renounce politics and political parties and that they turn into spectators who observe how technocratic elites adopt solutions that benefit the 'ordinary people' (cf. Urbinati, 2014). In sum, technocratic populism is a growing challenge to pluralistic forms of representative democracy. As such, it calls for a scholarly attention both from historical and comparative perspectives.

The thematic issue is composed of 11 articles that bring together 18 scholars from around the world with a wide variety of perspectives. Five case studies investigate the evolution, public support and consequences of technocratic populism for democracy in the Czech Republic (Guasti, 2020a), France (Perottino \& Guasti, 2020), Georgia (Aprasidze \& Siroky, 2020), Italy (Castaldo \& Verzichelli, 2020) and Spain (Ganuza \& Font, 2020). Three are also two-country comparisons. Piquer and Jäger (2020) see the cartelization of party systems as a driving factor for the rise of intra- and extra-party techno-populist logic, focusing on the UK and Spain. Snegovaya (2020) compares voter attitudes in France and the Czech Republic. Buštíková and Baboš (2020) explore governance during the Covid-19 pandemic in Czechia and Slovakia. Finally, three articles offer a broad cross-national perspective. Reiser and Hebenstreit (2020) explore the relationship between Euroscepticism and technocratic populism. Semenova (2020) examines the historical legacies of ministerial appointments in Eastern Europe. Barrenechea and Dargent (2020) offer a study of populist governance in Latin America.

\section{Five Lessons for the Future of Technocratic Populism}

This rich body of original research leads us to derive five lessons for future studies of technocratic populism. First, technocratic populism is a distinct sub-type of populism. Second, it tends to emerge when party systems weaken. Third, technocratic populists offer a direct, unmediated link to voters via expertise. Fourth, when in power, they combine populist responsiveness with expert-driven responsibility. Finally, the pandemic facilitates democratic decay and enhances the appeal of technocratic populism. We outline these lessons in more detail now before we summarize individual papers.

\subsection{Technocratic Populism is a Distinct Type of Populism}

Technocratic populism is a unique type of populism. It responds to a salient contemporaneous grievance of voters in many democracies related to sub-par governance by mainstream political elites. It is neither a residual category, nor a hybrid type defined by centrism. Populism co-exists with diverse host ideologies and logics, beyond nativism or socialism (cf. Art, 2020; Caiani \& Graziano, 2019; Zulianello, 2020). Furthermore, it cannot be automatically linked to illiberalism (Norris \& Inglehart, 2019).

\subsection{Technocratic Populism Emerges When Party Systems Weaken}

Two conditions are conducive for the emergence of technocratic populism - the implosion of the existing party system (Castaldo \& Verzichelli, 2020; Perottino \& Guasti, 2020) and the exhaustion of the left-right ideological cleavage (Buštíková \& Guasti, 2019). Technocratic populism combines the redemptive promise of populism with the technocratic promise of competent governance (Aprasidze \& Siroky, 2020; Perottino \& Guasti, 2020) and can restructure intra-party logic (Piquer \& Jäger, 2020). It rejects existing parties and political ideologies as obsolete and it attacks established and other populist parties as incompetent. Populist technocratic appeal enables new anti-establishment leaders to instrumentalize competence, civility and impartiality of knowledge to distinguish themselves from the populist radical right as well as the left (cf. Buštíková, 2020).

\subsection{Technocratic Populism Opposes Mediated Politics}

Technocratic populism is a strategy to directly appeal to voters and it uses the public's trust in knowledge and expertise as a legitimacy shield (Rosanvallon, 2011). Unmediated politics replace accountability (Guasti, 2020a), through direct channels of communication (Buštíková \& Guasti, 2019), democratic innovations (Perottino \& Guasti, 2020) and alternative crisis management bodies (Buštíková \& Baboš, 2020). Populist leaders concentrate power when they circumvent established institutions and remove expertise from public scrutiny.

\subsection{Technocratic Populism Combines Responsiveness (Populism) with Responsibility (Technocracy)}

In a crisis, the tension between responsiveness and responsibility increases. When technocratic populists are unable to control negative policy trends, they favor 
responsiveness at the expense of responsibility. Selected experts serve at the pleasure of the populist leader. Therefore, unpopular experts are replaced, and popular experts serve to increase the leader's appeal and legitimacy. This leads to the prioritization of policies that deliver instantaneous popularity boosts rather than complex, responsible policies with long-term horizons (Buštíková \& Baboš, 2020; Guasti, 2020a; Perottino \& Guasti, 2020).

\subsection{The Pandemic Facilitates Democratic Decay}

To solve the unprecedented Covid-19 health crisis, leaders have to engage with epidemiologists and public health officials. Because they emphasize expertise, technocratic populists might initially benefit from the surge in demand for non-political medical knowledge during the pandemic (Guasti, 2020b). Technocratic populists conceal accountability by hiding behind experts and by shifting decisions on pandemic responses outside of the parliamentary arena. This instrumentalization of technocratic expertise then justifies executive aggrandizement (Bermeo, 2016) which contributes to democratic decay.

\section{Overview of Contributions}

Now we turn to a brief description of the articles in the order that they appear in the thematic issue.

Guasti (2020a) focuses on the effects of technocratic populism in power on democracy. She highlights the illiberal tendencies of technocratic populism in power, best expressed in executive aggrandizement. Without the restraint of institutional veto points and civil society, technocratic populism undermines electoral competition (vertical accountability), judiciary independence, legislative oversight (horizontal accountability), and freedom of the press (diagonal accountability).

Castaldo and Verzichelli (2020) highlight the interplay between technocracy and populism in Italy. They show the variability of anti-establishment and technocratic appeals: a business outsider taking on the system (Berlusconi); a popular technocrat unsuccessfully trying to turn popularity into electoral success avoiding populism (Monti, Conte); an insider trying to mix populist party leadership with a technocratic executive style (Renzi); and, finally, a populist replacing technocratic appeal with nativism (Salvini). Thus, while latent in Italy, the interplay between technocracy and populism comes in many forms, and adapts and persists over time.

Buštíková and Baboš (2020) explore how populists govern in crisis. They focus on the actions of technocratic populists in power during the first wave of the Covid-19 crisis in the Czech Republic and Slovakia. They identify three features of the populist pandemic response: bypassing established, institutionalized channels of crisis response, responsive policy making and politicization of expertise.
Barrenechea and Dargent (2020) scrutinize conflict cohabitation and cooperation between populists and technocrats in Latin America. They find that cohabitation is more common than conflict and that conflict is moderated by two conditions: the programmatic mandate of populists and the economic context of their rise to power.

Ganuza and Font (2020) analyze public opinion towards technocracy using a unique survey and focus group data from Spain, where a political party, Ciudadanos (Citizens) deploys technocratic populism. They find that, while most citizens are dismayed with the inefficiency of established political parties and in favor of a generic idea of politics with experts, people lean towards a consultative role of experts in politics and support representative democracy.

Piquer and Jäger (2020) investigate two left-wing subtypes of technocratic populism at the party level: Corbynism in the United Kingdom and Podemos in Spain. They find that technocratic traits result from the cartelization of party systems, but also from electoral contexts and policy environments increasingly dominated by expert claims and expert institutions. The Covid-19 crisis has reinforced the technocratic aspects of Podemos as a governing party.

Perottino and Guasti (2020) analyze the electoral success of Emmanuel Macron, who combined personal charisma and technocratic expertise to win the presidency in 2017. Technocratic populism enabled Macron to transcend the political left and right while simultaneously fending off radical populist competitors. Macron refused traditional labels (centrism), elite recruitment patterns, and mediated politics. Instead, he created new forms of responsiveness by 'giving voice to the people' while at the same time relying on technocratic competence.

Snegovaya (2020) compares support for the rightwing parties and technocratic populists in France and the Czech Republic. She finds that voters for right-wing populists share many common features, but voters for technocratic populists have few commonalities aside from higher levels of trust in political institutions.

Reiser and Hebenstreit (2020) investigate the interplay between populism and Euroscepticism at the party level. They show that left- and right-wing populist parties articulate different anti-technocratic positions, in line with their respective host ideology. The technocratic critique of the EU is more complex for technocratic populists, who rely on technocratic appeals domestically. Some (ANO 2011 and GERB) do not have a critical stance towards EU technocracy, while others (M5S and OL'aNO) have utilized technocratic critiques of the EU as a part of their (soft) Eurosceptic posture.

Aprasidze and Siroky (2020) argue that in a hybrid regime, technocratic populism is utilized as a façade to cover authoritarian and oligarchic tendencies and inhibit democratization efforts. Bidzina Ivanishvili came to power in 2012 and, despite not holding any official 
position in the government, has since ruled Georgia by proxies using corporatist and patrimonial forms of governance.

Semenova (2020) examines the appointments and survival of expert ministers in eleven Central and Eastern European countries over two decades (1990-2012). Her analysis shows that communist legacies contribute to a congruence between technocratic appointments and public expectations for expertise in government.

\section{Conclusions}

Technocratic populism is a distinct type of populism. It emerges when party systems are weakened and issues of governance gain salience. It opposes mediated politics and combines responsiveness (populism) and responsibility (technocracy). The Covid-19 crisis is uniquely conducive to the appeal of technocratic populism: The demand for public health expertise is at an all-time high, and good governance is a matter of life and death. This thematic issue shows that the dual approach of technocratic populism to governance makes it competitive against the established parties as well as the right- or left-wing populist parties. When in power, technocratic populism exploits ambiguity: It is flexible in its appeal, but also volatile and diffuse when it comes to the sources of its public support (Buštíková \& Baboš, 2020; Perottino \& Guasti, 2020; Snegovaya, 2020). Future research should study technocratic populism alongside more traditional types of populism and might focus on the sources of its appeal, executive competence, and its effect on liberal democracy.

\section{Acknowledgments}

The study that originated this thematic issue has been completed with funding from the Strategy AV21 of the Czech Academy of Sciences, research programme No. 15-Global Conflicts and Local Interactions: Cultural and Social Challenges. We would also like to thank participants of the international workshop "Anti-Elitism: Varieties of Technocratic Populism around the World" held at the Friedrich Schiller University in Jena, 10-11 February, 2020, for comments and discussion of the thematic issue, and to Vello Pettai for feedback to the authors. We would like to most warmly thank to David Siroky for extensive comments on this introduction.

\section{Conflict of Interests}

The authors declare no conflict of interests.

\section{References}

Aprasidze, D., \& Siroky, D. (2020). Technocratic populism in hybrid regimes: Georgia on my mind and in my pocket. Politics and Governance, 8(4), 580-589.

Art, D. (2020). The myth of global populism. Perspec- tives on Politics. Advance online publication. https:// doi.org/10.1017/S1537592720003552

Barrenechea, R., \& Dargent, E. (2020). Populists and technocrats in Latin America: Conflict, cohabitation, and cooperation. Politics and Governance, 8(4), 509-519.

Bermeo, N. (2016). On democratic backsliding. Journal of Democracy, 27(1), 5-19.

Bickerton, C., \& Accetti, C. I. (2017). Populism and technocracy: Opposites or complements? Critical Review of International Social and Political Philosophy, 20(2), 186-206.

Bickerton, C., \& Accetti, C. I. (2021). Technopopulism: The new logic of democratic politics. Oxford: Oxford University Press.

Buštíková, L. (2020). Extreme reactions: Radical right mobilization in Eastern Europe. Cambridge: Cambridge University Press.

Buštíková, L., \& Baboš, P. (2020). Best in Covid: Populists in the time of pandemic. Politics and Governance, 8(4), 496-508.

Buštíková, L., \& Guasti, P. (2019). The state as a firm: Understanding the autocratic roots of technocratic populism. East European Politics and Societies, 33(2), 302-330.

Caiani, M., \& Graziano, P. (2019). Understanding varieties of populism in times of crises. West European Politics, 42(6), 1141-1158.

Caramani, D. (2017). Will vs. reason: The populist and technocratic forms of political representation and their critique to party government. The American Political Science Review, 111(1), 54-67.

Castaldo, A., \& Verzichelli, L. (2020). Technocratic populism in Italy after Berlusconi: The trendsetter and his disciples. Politics and Governance, 8(4), 485-495.

Ganuza, E., \& Font, J. (2020). Experts in government: What for? Ambiguities in public opinion towards technocracy. Politics and Governance, 8(4), 520-532.

Guasti, P. (2020a). Populism in power and democracy: Democratic decay and resilience in the Czech Republic (2013-2020). Politics and Governance, 8(4), 473-484.

Guasti, P. (2020b). The impact of the Covid-19 pandemic in Central and Eastern Europe: The rise of autocracy and democratic resilience. Democratic Theory, $7(2)$, 47-60.

Kaltwasser, C. R. (2014). The responses of populism to Dahl's democratic dilemmas. Political Studies, 62(3), 470-487.

Majone, G. (1994). The rise of the regulatory state in Europe. West European Politics, 17(3), 77-101.

Norris, P., \& Inglehart, R. (2019). Cultural backlash: Trump, Brexit, and authoritarian populism. Cambridge: Cambridge University Press.

O'Donnell, G. (1994). The state, democratization, and some conceptual problems (a Latin American view with glances at some post-communist countries). In W. C. Smith, C. H. Acuña, \& E. A. Gamarra (Eds.), Latin American political economy in the age of neoliberal 
reform (pp. 157-179). New Brunswick, NJ: Transaction Books.

Perottino, M., \& Guasti, P. (2020). Technocratic populism à la Française? The roots and mechanisms of Emmanuel Macron's success. Politics and Governance, 8(4), 545-555.

Piquer, J., \& Jäger, A. M. M. (2020). After the cartel party: 'Extra-party' and 'intra-party' techno-populism. Politics and Governance, 8(4), 533-544.

Reiser, M., \& Hebenstreit, J. (2020). Populism versus technocracy? Populist responses to the technocratic nature of the EU. Politics and Governance, 8(4), 568-579.

Rosanvallon, P. (2011). Democratic legitimacy: Impartiality, reflexivity, proximity. Princeton, NJ: Princeton University Press.

Semenova, E. (2020). Expert ministers in new democra- cies: Delegation, communist legacies, or technocratic populism? Politics and Governance, 8(4), 590-602.

Snegovaya, M. (2020). Different strokes for different folks: Who votes for technocratic parties? Politics and Governance, 8(4), 556-567.

Taggart, P. (2002). Populism and the pathology of representative politics. In Y. Mény \& Y. Surel (Eds.), Democracies and the populist challenge (pp. 62-80). London: Palgrave Macmillan.

Urbinati, N. (2014). Democracy disfigured. Cambridge, MA: Harvard University Press.

Zulianello, M. (2020). Varieties of populist parties and party systems in Europe: From state-of-the-art to the application of a novel classification scheme to 66 parties in 33 countries. Government and Opposition, 55(2), 327-347.

\section{About the Authors}
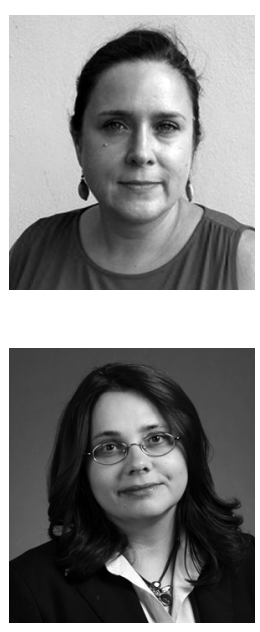

Petra Guasti is a Senior Researcher at the Institute of Sociology of the Czech Academy of Sciences and a Postdoctoral Researcher at the University of Jena. In academic year 2018/2019 she was a Democracy Visiting Fellow at the Ash Centre for Democratic Governance and Innovation, Harvard Kennedy School. Her main research focus is the growing tension within the system of representative democracy in respect to its legitimacy. Her research appears in Democratic Theory, Democratization, Communist and Post-Communist Studies, among others.

Lenka Buštíková is an Associate Professor in the School of Politics and Global Studies at Arizona State University. Her research focuses on party politics, voting behavior, clientelism, and state capacity. Her book, Extreme Reactions: Radical Right Mobilization in Eastern Europe (Cambridge University Press), demonstrates that far right parties mobilize against politically ascendant minorities. It received the Davis Center Book Prize in political and social studies. She is currently serving as an Editor of East European Politics. 